\title{
Global Value Chains and Economic Diplomacy
}

\author{
Ari Van Assche, HEC Montreal, Canada \\ Thierry Warin, SKEMA Business School, France
}

\section{Introduction}

With President Trump disrupting the rule-based trading system and using tariffs to try to bring jobs and investments back into the United States, there is currently no shortage of discussion about economic diplomacy. Around the world, governments are grappling with how they can help their national firms to cope with the fallout from rising protectionism. They also seek to modernize diplomatic tools to promote certain types of international business (IB) that advance their countries' economic interest.

The focus on economic diplomacy is not new, with the subject having received spurts of attention during times of both rising multilateralism (e.g., after GATT implementation) and mounting protectionism (e.g., after September 11, 2001). What is new about the current cycle of interest, however, is the pace of change within diplomatic services and the amount of resources that are dedicated to economic diplomacy.

In this context, recent scholarship acknowledges the need for a comprehensive analytical framework of economic diplomacy, which can shape our understanding of its activities, tools, and goals. Several recent studies have indeed started combining elements from the fields of international relations and international political economy to capture both the economic and political dimensions of economic diplomacy (e.g., Okano-Heijmans 2011).

However, what is often overlooked in this discussion, and will be the central argument of this article, is that any comprehensive economic diplomacy framework requires a strong understanding of IB. Economic diplomats commonly focus on export promotion and inward foreign direct investment (FDI) attraction, while avoiding import attraction and outward FDI promotion. We illustrate in this article that this approach is built on wrong premises and discuss how IB scholarship can aid in the development of new frameworks that allows for more effective economic diplomacy strategies.

\section{What Is Economic Diplomacy?}

"Economic diplomacy" came in vogue at the end of the $20^{\text {th }}$ century as a growing number of countries overhauled their diplomatic services to increase their economic influence. Kostecki and Naray (2007) define economic diplomacy as a government service to the business community, which aims at the development of socially beneficial international business ventures. It implies the use of a range of diplomatic tools (intelligence gathering, lobbying, representation, negotiation, and advocacy) by public officials from diplomatic missions to support the promotion of certain types of trade and foreign direct investments that advance the country's economic interest. This includes the organization of trade missions, the creation of export and investment promotion agencies, and the deployment of diplomatic resources towards economic intelligence.

The justification for economic diplomacy is the existence of externalities related to intelligence gathering about market conditions and business opportunities in foreign markets. Competition makes firms hesitant to share economic intelligence about foreign markets with their national competitors. Because governments have different priorities, they often step in to provide national firms impartial access to information about foreign markets, thus reducing firms' transaction costs and diminishing their liability of foreignness.

In this article, we do not question economic diplomacy's rationale to strengthen a country's international competitive- 
ness. Rather, we use recent IB insights on global value chains (GVCs) to ask whether economic diplomats target the right IB-based economic diplomacy practices to strengthen a country's trade performance.

\section{Traditionall View of Economic Diplomacy}

A key assumption in traditional economic diplomacy theories is that production is local, but markets are global. This local value chains (LVC) view of IB has conditioned scholars' thinking about economic diplomacy in important ways. If production is concentrated within national boundaries, then firms have a single overriding motive for conducting international trade: to reach foreign consumers. For example, Canadian firms export their "Made in Canada" products to foreign consumers. Canadian imports reflect foreign-made goods that extra-territorial firms sell to Canadian customers.

The complementary relationship between exports and domestic employment provides governments with a justification to develop diplomatic tools that promote exports. Most countries nowadays run active export promotion programs (EPPs) to facilitate national firms' exports into foreign markets. These EPPs involve the provision of export credit insurance and subsidies associated with export requirements. But EPPs also include a series of export-support services that economic diplomats provide to help national firms overcome trade frictions. Economic diplomats help firms find and understand new markets by providing information on the general export process and specific markets, disseminating information on national firms' goods and services, and organizing trade fairs and missions. A vast literature has studied the optimal design of EPPs as well as their impacts on firm performance (e.g., Moons \& Bergeijk 2017). Germany is often identified as a country that effectively manages its EPPs.

In contrast, the perception that imports are made by foreign workers and compete against domestically produced output discourages most governments from promoting imports. This bias against imports has been further fueled by a recent study which shows that import shocks from China impose substantial labor adjustment costs on US blue-collar workers, negatively affecting their lifetime income and even their health and marriage prospects (Autor et al., 2014). This is not to say that import promotion programs are completely absent. A few countries have import promotion offices to support SMEs from developing economies (e.g., Netherlands Centre for the Promotion of Imports from Developing Countries). The mandate of these organizations, however, is to support international development and not to spur national economic performance.
The LVC view also shapes economic diplomats' thinking about FDI. If firms concentrate their production within national boundaries, then they have two key motives to conduct outward FDI: to move production close to consumers (market-seeking) or to shift it in the proximity of natural resources (resource-seeking). In both cases, governments consider outward FDI to be a substitute for domestic employment, and therefore something that should be avoided. In contrast, inward FDI should be encouraged since it brings many benefits to the country including jobs, capital, and advanced technology. A substantial literature has described the inward FDI policies such as tax breaks, infrastructure constructions, and loans that economic diplomats use to attract inward FDI (e.g., Tavares-Lehmann et al., 2016). The success of China's export-led growth strategy is often attributed to the country's ability to attract labor-intensive FDI through duty exemptions and tax reductions.

Taken together, the LVC view of IB has provided a strong underpinning for the so-called New Mercantilist paradigm that dominates today's thinking: any economic diplomacy strategy should be centered on the dual pillars of export promotion and inward FDI attraction.

\section{Reallity of Globall Vallue Chains}

The problem with the LVC view of IB is that it has never been so disconnected from reality as it is today. Following revolutionary declines in transport and communication costs, firms have long abandoned the practice of producing goods and services in a single country. Through offshoring and outsourcing,

\section{The problem with the $L V C$ view of $I B$ is that it has never been so disconnected from reality as it is today.}

they have fragmented their production processes and dispersed activities to different countries around the globe, leading to what are known as GVCs. GVCs have been documented in various industries ranging from footwear to telecommunications and services. There is growing evidence that GVCs are transforming locations by pushing them to move from an industrial to a functional specialization (Timmer et al., 2018). 
IB scholars were quick to recognize that firms' ability to geographically disperse value chain activities provide additional economic incentives to conduct IB. Firms now build or link with activities in foreign countries to obtain cheaper or higher quality inputs, allowing for productivity improvements (effciency-seeking). Other firms set up or connect to multiple activities in different foreign locations, letting them build resilience and operating flexibility (flexibility-seeking). And some firms build pipelines to foreign locations to tap into knowledge pockets that are not available locally, beefing up their innovation capability (knowledge-seeking).

One may even argue that the existence of GVCs has become axiomatic in current IB scholarship. Researchers commonly characterize the MNE as a network orchestrator of cross-border value-creating activities, some of which are carried out within the hierarchy of the firm and some which are conducted through informal social ties or contractual relationships. A familiar research theme in current research is how MNEs nurture their firm-specific advantage by using their network resources to reduce costs, connect to stronger partners, and access foreign technology (Cano-Kollmann et al., 2016).

However, a shortcoming of IB scholarship is that it has paid little attention to policy implications: despite deep knowledge about the way firms orchestrate GVCs, IB scholars have not sufficiently examined how GVCs affect broader social and economic issues. There are nonetheless a number of policy insights specifically related to economic diplomacy strategies that we can derive from existing GVC studies.

\section{Imported Inputs Can Strengthen the Local Economy}

There is ample empirical evidence that imported inputs, which take place within GVCs, are a key source of technology spillovers for national firms. They allow firms to improve their productivity, to develop new products, and to conduct quality upgrading. Country-level data also show that integration in GVCs is good for a country's growth: imported input growth is positively related with both industry-specific employment and output growth (Van Assche, 2017). As a consequence, there is a growing call for policymakers to reduce trade restrictions on imported inputs.

\section{Outward FDI Can Spur Local Employment and Growth}

IB scholarship has widely established that outward FDI can enhance a firm's scale of operation and knowledge creation, and that these firm-specific benefits may spur positive externalities in the home country, which can stimulate growth and renew a nation's competitive advantages. Outward FDI is not necessarily a substitute of domestic jobs. Focusing on US MNEs, Harrison and McMillan (2011) found that employment by an MNE's foreign subsidiaries is complementary with its employ- ment in the United States, and especially when the subsidiaries are located in high-income countries. Bathelt and Buchholz (2018) showed that outward FDI positively affects the median income per capita of US counties. As a consequence, there is a growing acknowledgement that FDI policy should focus not only on inward FDI attraction but also on outward FDI promotion (Buckley, 2018).

\section{Focusing on only the traditional}

pillars of economic diplomacy export promotion and inward FDI attraction - has become antiquated.

\section{Economic Diplomacy Strategies Should Be Place-Sensitive}

Countries specialize in different types of activities and therefore may benefit from exposure to different kinds of assets and knowledge flows through IB. Depending on a location's specialization profile, economic diplomats could therefore promote a distinct international connectivity strategy to catalyze local economic growth (Iammarino, 2018). Turkina and Van Assche (2018) provided empirical evidence of the need for place-sensitive policies in the case of industrial clusters. Most developed country clusters compete to attract and retain knowledge-intensive activities, and it is improvements in horizontal connectivity (both inward and outward) to other knowledge hotspots that disproportionately allows them to do so. In developing countries, innovation catch-up depends on the ability to climb up the value chain, and it is thus improved vertical connectivity to more central value chain players that disproportionately allows firms to upgrade.

\section{Implications for Economic Diplomacy}

Our key message is that focusing on only the traditional pillars of economic diplomacy - export promotion and inward FDI attraction - has become antiquated. It is based on the premise that firms predominantly use IB to reach foreign consumers, but this is far from reality. A growing number of firms use IB to develop more efficient production processes, diminish supply chain risk, and enhance access to foreign knowledge. The success of these GVC business models depends not only on firms' ability to obtain reliable information on foreign markets but also on their capability to gather economic intelligence on potential GVC partners and possible outward FDI opportunities. Given the free rider problem that these firms face, there 
is a clear role for economic diplomats to step in and provide a broader set of services to stimulate IB that goes beyond export promotion and inward FDI attraction, particularly if it helps national firms to strengthen their position in GVCs.

This is not to say that we advocate for a blank slate, acrossthe-board promotion of all types of IB transactions. It is well established that any type of IB transaction can generate both winners and losers. Rather, we call for countries to develop comprehensive, place-sensitive economic diplomacy strategies that are built upon a careful empirical analysis of the differential consequences of distinct types of IB activities, and take the existence of GVCs as a starting point. Implementing such strategies will require countries to enhance their diagnostic tool kit, and - we acknowledge - it will require economic diplomats to have a more complex perspective on current global dynamics. We firmly believe that IB scholars can provide academic support in the process, particularly as the field deepens its interest on the policy dimension of IB research.

\section{References}

Autor, D., Dorn, D., Hanson, G., \& Song, J. 2014. Trade adjustment: worker level evidence. Quarterly Journal of Economics, 129(4): 1799-1860.

Bathelt, H., \& Buchholz, M. 2018. Outward foreign direct investments as a catalyst of urban-regional income development? Evidence from the United States. SPACES online, 14(2): www.spaces-online. com.

Buckley, P. 2018.Towards a theoretically-based global foreign direct investment policy regime. Journal of International Business Policy, 1(3-4): 184-207.

Cano-Kollmann, M., Cantwell, J., Hannigan, T. J., Mudambi, R., \& Song, J. 2016. Knowledge connectivity: An agenda for innovation research in international business. Journal of International Business Studies, 47(3): 255-262.

lammarino, S. 2018. FDI and regional development policy. Journal of International Business Policy, 1 (3-4): 157-183.

Kostecki, M., \& Naray, O. 2007. Commercial diplomacy and international business. Den Haag: Netherlands Institute of International Relations "Clingendael".

Moons, S., \& van Bergeijk, P. 2017. Does economic diplomacy work? A meta-analysis of its impact on trade and investment. The World Economy, 40(2): 336-368.

Okano-Heijmans, M. 2011 . Conceptualizing economic diplomacy: The crossroads of international relations, economics, IPE and diplomatic studies. The Hague Journal of Diplomacy, 6(1): 7-36.

Tavares-Lehmann, A., Toledano, P., Johnson, L., \& Sachs, L. (Eds). 2016. Rethinking Investment Incentives: Trends and Policy Options. New York: Columbia University Press.

Timmer, M., Miroudot, S., \& De Vries, G. 2019. Functional specialization in trade. Journal of Economic Geography, forthcoming.
Turkina, E., \& Van Assche, A. 2018. Global connectedness and local innovation in industrial clusters. Journal of International Business Studies, 49(6): 706-728.

Van Assche, A. 2017. Global value chains and the rise of a supply chain mindset. In S. Tapp, A. Van Assche, \& R. Wolfe (Eds), Redesigning Canadian trade policies for new global realities: 183-208. Montreal: McGill Queen's University Press.

Ari Van Assche (ari.van-assche@hec.ca) is Associate Professor of International Business at HEC Montreal and deputy editor of the Journal of International Business Policy. Recipient of a Ph.D. in Economics from the University of Hawaii at Manoa, his research focuses on the organization of global value chains and their implications for international trade and industrial clusters.

Thierry Warin (thierry.warin@skema.edu) is Professor of Data Science and Finance at SKEMA Business School. An Academic Editor at Plos One, he is the director of the SKEMA Augmented Intelligence Global Lab. He received his PhD from Essec Business School, France. His research focuses mainly on the dynamics of global integrations both financial and technological, using data science (predictive modelling, big data, network analysis) as a methodology of choice. 